\title{
Riikka Rossi
}

\section{Strukturalismi ja suuret aatteet - keskustelu Philippe Hamonin kanssa}

\begin{abstract}
"Vuosi 1966 oli todella poikkeava, erityislaatuinen vuosi", muistelee ranskalainen emeritusprofessori Philippe Hamon tutkijanuransa alkuvaiheita vallankumousten vuosikymmenellä. Hamon on nykyisin yksi arvostetuimmista realismin, ironian ja kuvauksen tutkijoista. Muun muassa teoksistaan Du descriptif (1993) ja Lironie littéraire (1996) tunnettu Hamon oli tuolloin juuri saanut lisensiaattityönsä päätökseen ja suunnitteli akateemista uraa Sorbonnen yliopistossa Pariisissa.

"Yhden ainoan vuoden aikana ilmestyi joukko julkaisuja, jotka muuttivat Ranskan kirjallisuudentutkimuksen suunnan sekä häikäisivät ja hätkähdyttivät nuoria kirjallisuudentutkijoita: A. J. Greimasin teos Sémantique structural du récit, Michel Foucault'n Les mots et les choses, Roland Barthesin Critique et vérite. Strukturalistinen kirjallisuudentutkimuksen suuntaus alkoi muotoutua. Kuten François Dosse huomauttaa teoksessaan Histoire du structuralisme (1992), olemme kaikki vuoden 1966 lapsia”, sanoo Hamon, josta tulikin Barthesin, Tzvetan Todorovin ja Gérard Genetten ohella yksi 1960-luvulla syntyneen ranskalaisen koulukunnan kärkinimistä. ”Vuodet 1965-1966 olivat murrosaikaa, jonka kaltaisia mahtuu muutama yhteen vuosisataan kussakin kulttuurissa”, hän lisää.

Hamon ei turhaan kuvaile 1960-luvun loppua "ennennäkemättömäksi”. Se merkitsi käännekohtaa ranskalaisen kirjallisuudentutkimuksen historiassa ja nousua kansainväliseen kärkeen. 1960-luvun alussa ranskalainen kirjallisuudentutkimus laahasi vielä pahasti jäljessä anglosaksiseen kielialueeseen verrattuna. Hamonin tuolloinen opinahjo, vuonna 1253 perustettu Sorbonne, tunnettiin konservatiivisena yliopistona, jossa ainoa kirjallisuudentutkimuksellinen metodi oli biografismi. ”Teoksia luettiin kirjailijan elämäkerran ja vaikutusten valossa”, Hamon muistelee. Tähän traditioon Barthesin ajatukset "tekijän kuolemasta" iskivät aivan toisella tavalla kuin vaikkapa Yhdysvaltoihin tai Neuvostoliittoon, joissa oli uuskritiikin ja formalismin myötä totuttu tekstilähtöisempään tutkimukseen. Uusien, ulkomaisten ideoiden leviämistä Ranskaan hidasti käännösten puute. Esimerkiksi venäläinen formalismi tuli Ranskaan vasta 1960-luvulla, jolloin muun muassa Todorov käänsi formalistien kirjoituksia Ranskaksi: Todorovin käännösantologia Théorie de la littérature, textes des formalistes russes ilmestyi tietenkin vuonna 1966.
\end{abstract}

"Me nuoret, silloin noin 25-vuotiaat tutkijat janosimme jotakin uutta tapaa tarkastella kirjallisuutta. Sorbonnen biografismin sijaan halusimme lukea tekstejä uusien lä- 
hitieteiden, kuten strukturalistisen antropologian, psykoanalyysin ja sosiologian valossa”, Hamon kuvailee. Paradigman murrokseen kannusti myös 1970-luvun vaihteessa toteutettu yliopistouudistus. Vanha Sorbonne jaettiin 13 pienempään yksikköön, joista erityisesti Sorbonne Nouvellesta tuli biografismin pölyt itsestään karistaneen kirjallisuudentutkimuksen tyyssija. Hamon toimi siellä professorina vuosina 1989-2005.

1960-luvun koulukunnan kannalta tärkeä instituutio oli myös tutkimuslaitos École pratique des hautes études, jossa vaikutti muun muassa Barthes. Vuonna 1970 perustettu Poétique-lehti, jossa Hamon oli alusta asti mukana, tarjosi puolestaan julkaisukanavan perinteisestä poikkeavalle ajattelulle. Ja tietenkin taustalla vaikutti yleinen, radikalismiin kannustanut poliittinen ilmapiiri. Vuoden 1968 poliittinen kriisi ajoittui samaan aikaan strukturalismin läpimurron kanssa.

Strukturalistisen koulukunnan myötä biografismi vaihtui tekstikeskeisempään, erityisesti kertovien rakenteiden merkitystä pohtivaan analyysiin. Siinä missä Gérard Genette ja Tzvetan Todorov suuntautuivat narratologiaan, Philippe Hamon kiinnostui kertomuksen sijaan kuvauksen, ironian ja lajin käsitteistä. Hamonin tutkimuskohteeksi ja elämäntyöksi muotoutui Ranskan naturalismin isänä pidetyn Émile Zolan (1840-1902) romaanituotanto.

Jos strukturalistinen metodi edusti uutta paradigmaa, myös Hamonin aiheenvalintaa voisi pitää radikaalina. 1960-luvulla Zola ei Balzacin tai Flaubertin tavoin ollut suuren realistin saatikka kunnioitusta herättävän kansalliskirjailijan maineessa. Zola oli massiivisen tuotannon kirjoittanut, oman aikansa kansainvälisesti tunnetuin kirjailija, mutta hän ei koskaan päässyt Ranskan Akatemiaan. Ranskan suurmiesten rinnalle, Pariisin Panthéoniin, Zolan arkku siirrettiin vasta muutama vuosi hänen kuolemansa jälkeen. Aiemmin Zola tunnettiin jonkinlaisena "viihdekirjailijana, maallisena sosialistina", kuten Zola-tutkija Henri Mitterand kuvaa teoksessaan Zola et le naturalisme (1986).

Hamon ei itse kuitenkaan näe tutkimuskohteen valinnassa radikalismia: "Valitsin Zolan, koska ohjaajani Robert Ricatte ${ }^{1}$ suositteli häntä. En juuri tuntenut Zolaa tuolloin, mutta pidin aihetta sopivana, koska Zolasta ei juuri ollut olemassa tutkimusta”. Samaa ajatteli tuohon aikaan muutama muukin, ja 1960-luvun jälkeen Zolan tuotannon tutkimus lähti selvään nousuun. Zolan uudelleenarvioinnin kannalta merkitystä oli erityisesti vuonna 1981 perustetulla, CNRS:n ja ITEM:in² alaisuudessa toimivalla Zolan ja naturalismin tutkimuslaitoksella Centre des recherches sur Zola et le naturalisme, jonka johtajana Philippe Hamon oli vuosina 2000-2005. On varmasti juuri Centre Zolan ansiota, että käsitys Zolasta on monipuolistunut. Todellisuuden pintailmiöihin takertuvan dokumentaristin ja viihdekirjailijan sijaan Centre Zolan piirissä ohjatut väitöskirjat ja tutkimukset ovat tuoneet esille esimerkiksi Zolan tuotannon myyttisiä, romanttisia ja symbolisia ulottuvuuksia. On tutkittu Zolan teosten suhdetta muihin 
taiteisiin, kuten oopperaan. Zolan tekstejä on tarkasteltu myös tekstikriittisestä näkökulmasta, ja hänen tuotannostaan on julkaistu sanakirjoja ja käsikirjoituseditioita.

\section{Kirjallisuuden perikato?}

Kaikki eivät kuitenkaan muistele 1960-lukua yhtä rauhallisesti kuin Philippe Hamon. Suurien aatteiden aikana syntynyt strukturalismi on kuohuttanut Ranskassa viime aikoina etenkin Tzvetan Todorovin ansiosta. Todorov, joka Suomessa tunnetaan kenties parhaiten fantastista kirjallisuutta käsittelevästä tutkimuksestaan Introduction à la littérature fantastique (1970) julkaisi alkuvuodesta poleemisen esseen Littérature en péril (Kirjallisuus uhattuna).

Todorovin näkemys kirjallisuuden ja sen tutkimuksen nykytilasta on synkkä. Kirjallisuus, laajemmin koko kirjallisuusinstituutio, on ajautunut perikadon partaalle. Todorovin mielestä kirjallisuus ei enää toimi todellisuuden ymmärtämisen väylänä, vaan on kadottanut kontaktin teosten kuvaamaan maailmaan. Eikä Todorovin oma 1960luvun sukupolvi ole tilanteeseen osaton. Kirjassaan hän arvostelee strukturalismin "formalistista”, mekaanista rakenteiden analyysia, joka ei puhu kirjallisuuden kuvaamasta maailmasta vaan omista käsitteistään. Dekonstruktion ongelmana hän pitää yhden ainoan totuuden nimiin vannomista - nimittäin sen, ettei totuutta ole eikä se koskaan ole kenenkään saavutettavissa.

Kirjallisuutta itseään vaivaa puolestaan solipsismi. Nykykirjallisuuden muotilaji, kirjailijan omaan elämää hyödyntävä autofiktio kuvastaa Todorovin mukaan nykyisen kirjallisuudentutkimuksenkin ongelmana olevaa tilannetta, jossa "minän" ja "maailman" välinen kontakti on kadonnut, kun varmaksi oletetaan ainoastaan oma olemassaolo. Todorov on huolissaan etenkin siitä, että kirjallisuus ei enää kiinnosta nuoria: Ranskassa kieli- ja kirjallisuuspainotteisen linjan valitsee lukiossa enää 10 prosenttia opiskelijoista, kun luku oli joitakin vuosikymmeniä sitten 33. "Kouluissa ei opeteta sitä, mistä teokset puhuvat, vaan siitä, mistä kirjallisuudentutkijat puhuvat", Todorov huokaa. Koululaiset kyllä oppivat, mitä ennakointi ja takautuma tarkoittavat, mutta eivät sitä, mitä kirjallisuus merkitsee ja mitä kaikkea se voi saada aikaan yhteiskunnassa. Ja Todorovin mukaan kirjallisuus voi tehdä paljon: "rakastan kirjallisuutta, koska se auttaa minua elämään”, strukturalisti Todorov tunnustaa.

Kysyn Hamonin mielipidettä Todorovin tavasta syyllistää 1960-luvun jälkeistä teoriaa kirjallisuuden nykytilasta. "En tiedä, miten hyödyllistä on etsiä syyllisiä. Enkä usko, että strukturalismi on vastuussa kaikista maailman ongelmista. Uskon, että kirjallisuuden asemaa nyky-yhteiskunnassa uhkaa pikemminkin televisio kuin strukturalismi. Lisäksi täytyisi pystyä erottamaan toisistaan se, mitä tapahtui yliopistoissa 1970-luvulla ja mitä tapahtuu nyt kouluissa", Hamon pohtii. ”Asiat eivät ole niin yksinkertaisia." Hamonin mielestä kirjallisuudessa itsessään tapahtuneet muutokset 1960- ja 1970- 
luvuilla pohjustivat siirtymää tekstilähtöisempään lähestymistapaan. Esimerkiksi Alain Robbe-Grillet'n edustama "nouveau roman" ei ollut luonteeltaan erityisen yhteiskunnallinen ja omalta osaltaan kannusti strukturalistisen lähestymistavan läpimurtoon.

Hamon ei myöskään näe kirjallisuuden nykytilaa yhtä synkkänä kuin Todorov. Vaikka autofiktiota voi hänenkin mukaansa pitää esimerkkinä tietynlaisesta sisäänpäin kääntyneisyydestä, klassikkoromaanien mahtipontisuus ja epookkidraama kiinnostavat yhä. Suuret tarinat elävät, mutta niiden formaatiksi on tullut pikemminkin elokuva; esimerkkinä Hamon mainitsee Tarun sormusten herrasta. Sarjakuvan Hamon näkee puolestaan jatkokertomusromaanin perintönä.

Hamonin ohella Ranskassa on muitakin optimisteja. Le monde -lehti julkaisi maaliskuussa 2007 manifestin "Pour une 'littérature-monde' en français" (Ranskankielisen "kirjallisuus-maailman" puolesta), jonka oli allekirjoittanut 44 ranskankielistä nykykirjailijaa, joiden joukossa oli muiden muassa J. M. G. Le Clézio, Jean Vautrin ja Erik Orsenna. Artikkelia voi pitää kommenttina Todorovin syytöksiin nykykirjallisuuden solipsismista, sillä kirjailijat julistivat artikkelissa "maailman" paluuta kirjallisuuteen; monellakin tasolla. Jo temaattisesti se näkyy historian paluuna kirjallisuuteen. Kielellisellä tasolla on kyse maailmaa tavoittavan "referentin" paluusta. Toisaalta uusi monikulttuurisuus luo yhteyttä kirjallisuuden ja "maailman" välille - artikkelin allekirjoittaneiden joukossa olikin paljon muualta kuin varsinaisesti Ranskasta kotoisin olevia ranskankielisiä kirjailijoita.

\section{Kirjallisuus, mahdollisuuksien laboratorio}

Realistisen kirjallisuuden asiantuntijana Hamon on itse erikoistunut aikakauteen, jolloin kirjallisuus oli yhteiskunnallista. Naturalististen kirjailijoiden pyrkimyksenä oli tutkia elämää, selvittää arjen ongelmien syitä ja seurauksia - "voiko kirjailijalla olla jalompaa tehtävää", kuten Hamonin tutkima Émile Zola aikoinaan mahtipontisesti julisti. Myös strukturalismin syntyaikaa kehysti poliittinen radikalismi ja maailman muuttamisen halu, josta voi kenties löytää analogian 1800-luvun lopun aatteiden aikaan. Mutta poliittista suuntausta tekstilähtöisestä strukturalismista ei koskaan tullut, päin vastoin. Todoroville strukturalismi näyttäytyi itse asiassa eräänlaisena pakotienä aatteesta. Todorovin synnyinmaassa, kommunistivallan alaisessa Bulgariassa, kirjallisuudentutkimus oli valjastettu tukemaan marxilais-leninististä ideologiaa, ja tekstin rakenteisiin keskittyvä analyysi tarjosi ulospääsyn ideologiavoittoisesta tulkinnasta, Todorov kertoo kirjassaan.

Philippe Hamon ei kuitenkaan pidä siitä, että strukturalismi tuomitaan fiktiivisen tekstin maailmaan käpertyneeksi näpertelyksi. Hän ei myöskään lämpene amerikkalaisen kulttuurintutkimuksen ja ranskalaisen tekstintutkimuksen väliselle vastakkainasettelulle, johon usein törmää Suomessakin. Häntä itseään on myös vaikea luokitella 
varsinaisesti strukturalistiksi. ”En ole koskaan kirjoittanut yhtään puhtaan formalistista tutkimusta”, Hamon sanoo. Ja totta onkin, että pääosassa Hamonin tutkimuksia liikutaan enemmän kulttuurintutkimuksen ja strukturalismin välimaastossa; rakenteet ymmärretään laajasti tekstit ja kulttuuriset kontekstit läpäiseviksi, toinen toisiaan heijastaviksi ja monella tasolla näkyviksi ilmiöiksi, joiden monistuminen muistuttaa enemmänkin dekonstruktiivista merkitysten asteittaisuutta kuin strukturalistista yhteen kielioppiin palautuvaa järjestelmää. Esimerkiksi Hamonin teoksessa Expositions (1989), jossa pohditaan 1800-luvun arkkitehtuurin ja kirjallisuuden välistä suhdetta, lähtökohta on "exposition" (näyttely, esittely, näytteillepano, esitys) niin maailmannäyttelyjen aikakauden, tekstin rakenteen kuin 1800-luvun realistiselle romaanille tyypillisen dokumentaarisen ja ensyklopedisen tiedon esillepanon näkökulmasta. Tekstin ja kontekstin lomittumisen lisäksi tekstuaaliset rakenteet myös luovat todellisuutta ja vaikuttavat todellisuuteen, kuten Hamon osoittaa tutkimuksessaan L'Ironie littéraire (1996): kaksoisdiskurssina ironia horjuttaa todellisuuden yksiselitteisyyttä, manipuloi arvoja ja konstruoi aktiivisen lukijan, jonka on epäiltävä, tulkittava implisiittiseksi jäävä ja tunnistettava ironian kulttuuriset referentit - ironia luo lukijasta ironisen tekstin kanssatekijän.

"Historia tarvitsee muotoa", Hamon summaa ja jatkaa, ettei pidä myöskään "fiktion" ja "toden" välisestä vastakkainasettelusta. "Omissa kirjoituksissani en käytä koskaan sanaa "fiktio", hän kuvaa suhdettaan tekstin ja "maailman" häilyvään rajaan.

Mutta entä ne suuret aatteet? Litteratur en péril -teoksessa strukturalisti Todorov tunnustaa rakastavansa kirjallisuutta, koska kirjallisuus auttaa ymmärtämään maailmaa, kohtaamaan toisia ihmisiä ja lohduttaa masennuksen hetkinä. Mitä mieltä Philippe Hamon on kirjallisuuden tehtävästä? ”Nykyisin kirjallisuus ei toimi enää kuvitteellisen, fiktiivisen alueena, vaan enemmänkin laboratoriona, jonka luomia mahdollisia tapahtumasarjoja se tarjoaa yhteiskunnalle. Kirjallisuus vaikuttaa yhä yhteiskuntaan kierrättämällä vanhoja arvoja ja ideologioita sekä kritisoimalla vallankäyttäjien kieltä. Mutta kirjallisuus ei enää toimi samojen kanavien kautta kuin ennen, kuten klassikkojen ja koulujen välityksellä", Hamon toteaa ja viittaa Todorovin huolestuneisuuteen kirjallisuuden kouluissa menettämästä suosiosta. ”Kirjallisuus elää ja leviää internetin, blogien ja elokuvan kautta - ja elokuva on kuitenkin pikemmin kirjallisuuden liittolainen kuin vihollinen", Hamon pohtii.

Philippe Hamon vieraili Suomessa tammikuussa 2007 kirjoittajan vastaväittäjänä.

\section{Viitteet}

1 Robert Ricatte tunnetaan Goncourt'in veljesten tuotannon tutkijana, Création romanesque chez les Goncourts -teoksen (1953) kirjoittajana.

2 CNRS = Centre National de Recherche Scientifique; ITEM = Institut des textes et manuscripts modernes. 